\title{
MANAGEMENT OF ETHICAL BEHAVIOR OF AUDITORS
}

\author{
Iryna Drozd', Mariia Pysmenna², Vladlen Volkov³
}

\begin{abstract}
The purpose and tasks of the paper are to develop effective tools for the internal control at audit firms, including monitoring and self-assessment, to improve the quality of professional performance. The relevance of this study is determined by the high expectations of society to the quality of audit opinions. The information quality according to the results of the audit is achieved by adhering to strict professional standards and ethical conduct. Audit companies organize control over the implementation of ethical principles, which requires addressing issues of monitoring and self-assessment in the management of ethics. Methodology. The authors used deductive and empirical methods. The material for the development of conclusions on the organization of monitoring is collected upon the results of a survey of 150 auditors, accountants and managers of companies. 96 full responses (64\% of all respondents) were evaluated by five experts. The questions in the survey are designed to identify the audit experience of the ethics internal control organization in audit companies, and the results of its compliance assessment. Automated application capabilities of analysis and modeling of the program "1-C Accounting 8.0" were used for data processing. Results. The authors propose the auditors' compliance with ethical testing standards and calculations of the effectiveness indicators of the ethical values compliance as tools for assessing. The authors see the organization of such an element of internal control in the need to formulate clear ultimate goals for auditors. As goals need to be measured, the following criteria for assessing their achievement are proposed: ethical values are known and adhered to; senior management is aware of the ethical foundations and they serve as an example; staff understands and adheres to the code of conduct; active promotion of ethical principles by senior management. The authors conclude that ensuring leadership of senior management, both by example and in behavior is an important component of the implementation of organizational measures for ethical behavior. If such an ethical manner in the behavior of the company's management is achieved, it is an important positive contribution to the organization of the ethical behavior management: employees trust and feel confident in management decisions. Practical implications. Achieving the goals of managing ethical behavior of senior management can be recognized by the following criteria: senior management is recognized by co-workers as an example of high standards of behavior, willingness of senior management to be leaders in these issues and take action on misconduct, understanding individual and collective responsibility for compliance with high ethical standards. The implementation of objectives and organizational measures will achieve the defined criteria by monitoring the behavior of auditors on compliance with ethical standards. Taking into account the experience of audit companies, revealed during the survey, the authors propose to organize the monitoring of ethical behavior as an open, honest and transparent process. The awareness of all employees and ensuring confidence in its conclusions and results are the conditions for its establishment. According to the authors, the abovementioned is achieved through the availability of annual reports, regular assessment of the strengths and weaknesses of audit behavior, dissemination of information on the example of senior management in ethical behavior, staff awareness of the value of monitoring ethical behavior and their participation in annual surveys. Value/originality. The authors propose criteria for monitoring and self-assessment: incentives for all employees for good conduct, application of incentives and sanctions to overcome immoral acts, informing employees, effectiveness of incentives taking into account the specifics of
\end{abstract}

\footnotetext{
Corresponding author:

${ }^{1}$ Center of Advanced Training, Institute of Postgraduate Education,

Taras Shevchenko National University of Kyiv, Ukraine.

E-mail: drozdirina@ukr.net

ORCID: https://orcid.org/0000-0002-1930-2522

${ }^{2}$ Flying Academy of National Aviation University, Ukraine.

E-mail: mari.pismennaya.83@ukr.net

ORCID: https://orcid.org/0000-0003-4509-8147

${ }^{3}$ Scientific Institute of Public and Space Law, Ukraine.

E-mail: volkovvv2@ukr.net

ORCID: https://orcid.org/0000-0001-8419-9878
} 
Vol. 6, No. 4, 2020

high ethical culture of the audit company. The proposed measures will strengthen the elements of the internal quality control system and can be used in external evaluation of the quality of the audit company's activities. Implementation of proposals can lead to the organization of audit work on a high quality, responsible basis, which can increase the trust of users in the results of audit activity.

Key words: ethical principles, monitoring of ethical behavior, self-scoring of compliance with ethical norms, internal control of ethical rules, effectiveness of ethical behavior management.

JEL Classification: M14, M42

\section{Introduction}

Promoting public confidence in auditors and audit firms is based on the introduction of ethical conduct by auditors. It is determined by ethical principles and professional values. They reflect the model of personal development formulated taking into account the requirements of the International Financial Reporting Standards (IFRS) in the framework of the national policy (Gazabon, Cantillo \& Alvarez, 2017). Professional ethics is consistent with the values of mankind. The evolution of ethics in the new environment (Lachmann, 2013) requires adjustment of ethical values management in the professional field. Public reporting is based on public trust.

It is developed by users in the community based on regulatory requirements defined by the ethics code of the auditor (Code, 2012). Reliability is deeply based on the independence, impartiality and moral integrity of auditors, who must act in accordance with values and moral principles. Therefore, the audit firm must ensure that the described ethical standards are recognized as professional standards of conduct and are observed in the course of performing audit activities (Bondar, 2017).

In most cases, standards require auditors to act in accordance with the principles of honesty, independence, objectivity, impartiality, confidentiality and competence (Shvets \& Pavlik, 2018).

The organizational side of their implementation is based on the following. Each audit company that declares compliance with International Standards on Auditing, which are recognized in Ukraine as national, has the responsibility and obligation:

- to develop their own internal rules of ethics, clarifying ethical concepts based on the principles set out in the International Code of Ethics;

- ethical requirements are mandatory for auditors in the performance of their professional duties and in their personal lives;

- all auditors should be familiar with ethical values and principles;

- active promotion of the ethical conduct in the entire audit firm;

- actions of the top management of the audit firm should be an example of ethical behavior;

- audit firm must be governed by appropriate policies and procedures that guarantee its independence.
- the company's management should ensure the reduction of employees' conflicts of interests in the audit practices;

- prevent the internal conflicts of interest and corruption.

These aspects of ethical issues have aroused considerable interest among researchers (Nubia \& Díaz Ortega, 2018) and the search for conflict resolution.

\section{Materials and methods}

The key research question is a comprehensive study of the purpose and mechanisms of the influence of ethical principles on the quality of professional duties and the interaction of monitoring tools, self-assessment in the internal control system of the audit company.

Thus, a deductive approach is applied that is suitable for this type of conceptual research. The literature review was performed using the primary sources, by querying the databases of leading scientific journals via applied methods of analysis, synthesis, generalization and comparison.

The empirical method of data collection was the dominant research method by processing individually written answers to questions in the survey developed by the authors of this study. The questionnaire was evaluated by 5 audit experts. The survey of auditors was conducted in 2018-2019 during the advanced professional training of auditors, state accountants, managers at Taras Shevchenko National University of Kyiv. The purpose of the survey was to study and analyze the existing experience of auditing ethics to develop proposals for the organization of ethical behavior management, methodology and reporting.

The questions were aimed at assessing the situation with ethics management in audit companies, the results of the assessment of compliance with ethical principles. 96 out of 150 respondents (64\%) provided written answers to the questionnaire, guided by ideas, values and their own professional experience. The minimum sample size for analysis should be around 90 to 140 respondents (Volkova \& Emelyanov, 2012). Data processing was performed using the application program Analysis and Modeling in the audit "1-C Accounting 8.0".

\section{Theoretical prerequisites of the study}

Strengthening auditors' accountability for their findings is not just about strengthening their control 
over professional standards and in-depth knowledge. Here, the task of managing an audit firm includes strengthening, streamlining and consolidating management systems for ethics of business behavior with the development of realistic and practically implemented mechanisms of ethical control. These actions should be supported by auditors in their dayto-day operations (Sunyoto, Lely \& Agus, 2019).

The essence of professional ethics, although used by most auditors on a daily basis, is usually featuring a rather vague category of behavior in practice (Montaner \& Perozo, 2008).

A high level of ethics in auditing can help to prevent biased evaluations in audits and enhancing the reputation among stakeholders and society as a whole.

Ethics audit is a useful means of internal control of the audit firm compliance with ethical requirements, which ensures the implementation of the responsibility principle for honest and objective conclusions (Bakhtiari \& Azimifar, 2013).

However, in domestic auditing practice, ethical conduct is not the norm yet, despite the auditors' declaration of compliance with the ethical principles set out in the International Standards on Auditing. Internal rules and practices in audit firms regarding the management of auditors' ethical values have not become widespread yet.

Some authors (Bondar, 2017) believe that the control of ethical values should be provided by:

- effective legal framework that sets basic standards for ethical conduct;

- effective accountability mechanisms, such as internal control and external audit during quality control;

- law enforcement procedures and mechanisms for implementing and maintaining compliance with ethical standards;

- informing colleagues of the audit company about the facts of response to non-compliance with ethical standards.

Another group of authors (Shvets \& Pavlik, 2018) believes that ethics is a conscious choice of a model of behavior that corresponds to certain values and principles. This is confirmed by the Code of Ethics of Auditors (Code, 2012). It declares a system of values and principles that guide the daily work of controllers (auditors).

There are researchers who distinguish the key (basic) ethical principle among all others (Peña \& Bastidas, 2007). They believe that honesty is at the heart of all values of any code of ethics. Honesty is measured in terms of accuracy and fairness. Honesty requires auditors to adhere to standards of control and principles of professional ethics both in terms of form and substance. And the internal honesty of auditors is an important aspect, which is understood as not overstepping the authority to make management decisions when consulting the auditee.
Important circumstances of honesty include refusing to accept gifts or tokens of gratitude, avoiding relationships with responsible officials of the control object, not using own official position in personal interests, avoiding relationships that may involve the risk of corruption, not using and not disseminating information, received for the performance of their official duties, in order to obtain benefits for themselves or others.

However, the auditor's compliance with such behavior without internal beliefs, but only due to external circumstances is a rather difficult task (Szafran, 2014). Therefore, the search for tools that would provide constant monitoring of compliance with ethical values in the system of internal control is an important area of looking into the theory and practice of ethical standards in auditing.

\section{Results and extended opportunities for systematic assessment}

Organizational measures to implement this task are as follows:

- strengthening, streamlining and consolidating the ethics management systems for business conduct in an audit company with the development of realistic and practically implemented mechanisms for ethical control;

- measures of the audit regulatory bodies to promote the ethics of business behavior at enterprises and institutions.

The audit community is to ensure that the ethical principles described in the national law are recognized, respected and play an essential role in the quality of the work of auditors and audit firms.

In this context, it is widely accepted that each audit entity is responsible for:

- establishment and development of norms of ethical behavior;

- familiarization of auditors with the values and principles contained in the code;

- organizing the ethics in the company to ensure that senior management and employees act according to ethical standards;

-implementation of policies and practices in accordance with the Code of Ethics;

- the adoption of policies and procedures that guarantee independence;

- consideration of written applications in order to confirm compliance with ethical requirements;

- prevention of internal conflicts of interest and corruption;

- implementation of procedures allowing to report of violations of ethical norms timely, as well as taking appropriate measures to resolve them.

The study of ethical behavior management was based on a survey of auditors working in audit firms and in 
their practical work to comply with ethical standards. The information received is designed to develop recommendations in action planning to identify ethical frameworks and practices, define best practices, use and disseminate them during ethics training.

In addition to answering the questions posed, auditors provided important information about the experience of managing ethical behavior. The percentages indicated in the following analytical survey results were calculated based on the responses provided by 96 auditors (100\%).

Among other documents (question 3), which specify the duties of auditors to comply with ethical principles in audit companies, they mention the Declaration on financial interests and assets, obligations after termination of office (for the management), the use of official resources and equipment (for the management of the audit company).

The formalization of the obligation to comply with ethical principles (question 4) is implemented in auditing companies in the form of signing the following documents by the auditors: declarations of the Code of Ethics, declarations of compliance with ethical principles, guidance on ethical obligations on a regular basis.

As shown by the survey (question 5), only a small percentage of companies (11.5\%) have a special unit

Table 1

Survey results on auditors about situation in the ethical behavior management

\begin{tabular}{|c|c|c|c|}
\hline \multirow{2}{*}{ No } & \multirow{2}{*}{ Questions } & \multicolumn{2}{|c|}{ Result } \\
\hline & & number & $\%$ \\
\hline 1 & $\begin{array}{l}\text { What documents contain approved ethical values in your audit company? } \\
\text { a) general legal norms } \\
\text { b) specific legal norms (in relation to auditors) } \\
\text { c) general code of ethics (applicable to all auditors) } \\
\text { d) code of ethics } \\
\text { e) strategic documents of the company } \\
\text { e) rules of conduct } \\
\text { g) other }\end{array}$ & $\begin{array}{l}75 \\
63 \\
48 \\
47 \\
51 \\
33 \\
13\end{array}$ & $\begin{array}{l}78.1 \\
65.6 \\
50.0 \\
48.9 \\
53.1 \\
34.4 \\
13.5\end{array}$ \\
\hline 2 & $\begin{array}{l}\text { The documents/provisions mentioned in question } 1 \text { include: } \\
\text { a) statements about values and principles } \\
\text { b) explanation of the expected behavior } \\
\text { c) examples of dilemmas and complex situations } \\
\text { d) tools to be used } \\
\text { e) provisions on unlawful actions } \\
\text { e) specific provisions for managers } \\
\text { g) other }\end{array}$ & $\begin{array}{l}93 \\
61 \\
32 \\
44 \\
89 \\
27 \\
15\end{array}$ & $\begin{array}{l}96.8 \\
63.5 \\
33.3 \\
45.8 \\
92.7 \\
28.1 \\
15.6\end{array}$ \\
\hline 3 & $\begin{array}{l}\text { These documents/provisions cover the following issues: } \\
\text { a) conflicts of interest } \\
\text { b) gifts and hospitality } \\
\text { c) professional secrecy } \\
\text { d) sexual or moral harassment } \\
\text { e) other }\end{array}$ & $\begin{array}{l}93 \\
93 \\
93 \\
29 \\
34\end{array}$ & $\begin{array}{l}96.8 \\
96.8 \\
96.8 \\
30.2 \\
35.4\end{array}$ \\
\hline 4 & $\begin{array}{l}\text { Auditors and/or employees formally sign a commitment to comply with the ethical principles of the audit firm } \\
\text { Yes } \\
\text { No } \\
\text { No answer }\end{array}$ & $\begin{array}{c}52 \\
43 \\
1\end{array}$ & $\begin{array}{c}54.2 \\
44.7 \\
1.1\end{array}$ \\
\hline 5 & $\begin{array}{l}\text { Does an Ethics committee/Person/Consultant work in your audit firm? } \\
\text { Yes } \\
\text { No }\end{array}$ & $\begin{array}{l}11 \\
85 \\
\end{array}$ & $\begin{array}{l}11.5 \\
88.5 \\
\end{array}$ \\
\hline 6 & $\begin{array}{l}\text { Are there any tools in your auditing company that auditors can use for self-assessment of their ethical } \\
\text { values and principles, or to address their ethical dilemmas? } \\
\text { Yes } \\
\text { No } \\
\text { No answer }\end{array}$ & $\begin{array}{c}4 \\
91 \\
1\end{array}$ & $\begin{array}{c}4.2 \\
94.7 \\
1.1\end{array}$ \\
\hline 7 & $\begin{array}{l}\text { Are there any (other) ethical issues that are important for an audit firm to manage ethical behavior? } \\
\text { If so, please name them. } \\
\text { No, all questions are presented in the questionnaire } \\
\text { Yes, there are other important issues }\end{array}$ & $\begin{array}{l}77 \\
19\end{array}$ & $\begin{array}{l}80.2 \\
19.8\end{array}$ \\
\hline 8 & $\begin{array}{l}\text { Do you represent an audit company or work as an individual auditor (individual entrepreneur)? } \\
\text { a) an audit company } \\
\text { b) an individual auditor }\end{array}$ & $\begin{array}{c}93 \\
3\end{array}$ & $\begin{array}{c}96.8 \\
3.2\end{array}$ \\
\hline
\end{tabular}

Source: developed by the authors 
or person to provide recommendations and managers of ethical dilemmas and behavior, examples include the Ethics Committee, Ethics Director, Coordinator, Audit Adviser, whose mandate is to consider ethical issues.

Most of the auditors (94.7\%) acknowledge that they do not have tools for self-assessment related to ethical behavior (question 6). Those who really have such tools include them in the Code of Ethics and consider such work in the context of personal consultants.

Although only $19 \%$ of the surveyed auditors referred to additional topics related to ethical behavior management that were not mentioned in the survey, but they are quite important: specific areas where ethical principles are exposed to higher risks, recruitment, responses to illegal use of enterprise resources, including with elements of fraud, risk management, transparency and accountability for effective management, and ensuring responsibility, division of duties, policies and management procedures in the company as a whole.

These topics were used by the authors in developing proposals for organizing the management of ethical conduct of auditors.

As the study showed, there is a solid progress among practitioners and scholars on tools for implementing ethical values in the company. These tools include: plans for working meetings with employees, training in ethics, recruitment based on criteria for ethical conduct. However, we propose to take into account two other mandatory tools, such as testing and performance indicators for ethical conduct and methods for collecting data on compliance with ethical values. The latter tools will be easier to implement if the clear goals for auditors are being set. Therefore, the first stage in the implementation of the tools for ethical behavior is the clear definition of standards of conduct that would be known and understood by all employees of the audit company. The criteria for assessing achievement of goals are the following:

- ethical values are known and respected;

- senior management is aware of ethical foundations and serves as an example;

- the staff understands and complies with the code of conduct;

- active promotion of ethical principles by senior management.

As evident from these goals, an important part of the implementation of organizational measures for ethical behavior is to provide leadership in these issues of senior management, both in examples and in behavior. If such an ethical tone is achieved in the company's senior officials, then it is an important positive contribution to the management of ethical behavior: employees trust and feel confident in managerial decisions.

Achieving the goals of managing ethical behavior of senior officials can be recognized by the following criteria:
- senior officials are recognized by staff as an example of high standards of conduct;

- the willingness of senior officials to be leaders in these issues and take measures for incompliance.

- understanding the ethical code of individual and collective responsibility for maintaining high ethical standards.

The implementation of goals and organizational measures will achieve the identified goals through monitoring the behavior of auditors and their compliance with ethical standards. The condition for monitoring is an open, honest and transparent process, in which all employees are informed and have confidence in its findings and outcomes. This can be achieved through the following steps:

- annual reports are available to all employees;

- the strengths and weaknesses of the auditor's behavior are regularly evaluated and measured;

- the role of senior officials in matters of ethical behavior is known and understood;

- the staff understands the value of monitoring ethical behavior and participates in annual surveys.

The consequences of organizing internal control on compliance with ethical principles are also the components of the overall process of managing ethical behavior. It was then that the mechanisms of influence on auditors that allowed deviations from ethical principles were perceived as just and efficient, and the rewards system for exemplary behavior was fully understood and recognized.

Therefore, the result of management of ethical behavior can be estimated through the criteria:

- good standards of behavior are encouraged by all employees;

- incentives and sanctions are used to overcome violence and immoral acts;

- incentives and sanctions are known and understood by all employees;

- incentives and sanctions are effective in developing a high ethical culture of the audit firm.

\section{Conclusion}

Increasing the public and users' confidence in the audit findings regarding the accuracy of financial transactions and reporting of businesses is based on the auditors' compliance with high ethical professional standards. They are the guarantors of independence, objectivity, honesty during the audit activity.

Organization of ethical behavior management involves not only the existence of ethics regulations, but also the monitoring and evaluation of tools for their implementation. The survey conducted by the authors of the study showed that awareness of the need to comply with ethical standards and appropriate ethical behavior is largely implemented in the activities of the audit companies. The practices 
of most of them requires organizational measures to monitor and control the ultimate goals of compliance with ethical behavior, lack of conflict of interest, and other unethical cases in audit activities. We suggest the goals, monitoring criteria, self-assessment control tools as part of internal audit quality measures. The implementation of the proposals will help to direct the audit work organization on a qualitative, responsible basis, which will increase the users' confidence in the results of the audit activity.

Further research is aimed at identifying quality control tools that would facilitate the implementation of the results of internal control of compliance with ethical principles to enhance the reliability of auditors.

\section{References:}

Bakhtiari, M., \& Azimifar, M. (2013). Impact of professional ethics on financial reporting quality. Advances in Environmental Biology, vol. 7(10), pp. 2862-2866. Retrieved May 12, 2020 from: http://www.aensiweb.com/old/ aeb/2013/2862-2866.pdf

Bondar, V. P. (2017). Problemy zastosuvannya norm profesijnoyi etyky u diyalnosti audytoriv Ukrayiny [The problems of application of professional ethics in the activity of auditors of Ukraine]. Bulletin of ZhSTU, vol. 1(79), pp. 3-10. Retrieved May 12, 2020 from: http://nbuv.gov.ua/UJRN/Vzhdtu_econ_2017_1_3

Gazabon, O., Cantillo, A., \& Alvarez, M. (2017). Ethics and Social Responsibility of Accountants facing the International Financial Reporting Standards (IFRS) in Colombia. A Prospective Analysis. Revista Espacios, vol. 38(37), p. 14. Retrieved May 12, 2020 from: https://www.revistaespacios.com/a17v38n37/17383714.html

Kodeks etyky profesijnyx buxgalteriv [Code of Ethics for Professional Accountants] (2012). Retrieved May 12, 2020 from: http://195.78.68.18/minfin/document/81073/D6.pdf

Lachmann, P. (2013). Ethics Evolve. European Review, vol. 21 (S1), p. 109-113. doi: https://doi.org/10.1017/ S1062798713000161

Montaner, J., \& Perozo, J. (2008). Formación ética del Contador Público. Caso: Facultad de Ciencias Económicas y Sociales de la Universidad del Zulia. Revista de Ciencias Sociales (RCS), vol. XIV (2), pp. 379-387.

Nubia, I. \& Díaz Ortega (2018). Bibliometric review on the ethics of the public accountant: contributions and opportunities of research. Revista Espacios, vol.39, p. 34. Retrieved from: May 12, 2020 http://www.revistaespacios.com/ a18v39n39/18393934.html

Peña, A. E., \& Bastidas, M. C. (2007). La ética: fundamento en la adopción de las normas internacionales de contabilidad. Actualidad Contable FACES, vol. 10(14), pp. 118-128. Retrieved May 12, 2020 from: http://www.revencyt.ula.ve/storage/repo/ArchivoDocumento/acon/v10n14/articulo10.pdf

Shvets, V. \& Pavlik, I. (2018). Formation of the basic principles of ethics for specialists of accounting and analytical sciences in modern information economics. Bulletin of ZhSTU, vol. 2(84), p. 41.

Sunyoto, Y., Lely, N., \& Agus, A. (2019). The influence of experience, motivation and professional commitment on employee performance and job satisfaction at the audit firm in Indonesia. Revista Espacios, vol. 40(27), p. 25. Retrieved May 12, 2020 from: http://www.revistaespacios.com/a19v40n27/a19v40n27p25.pdf

Szafran, J. (2014). Przestrzeganie kodeksu etyki audytora wewnętrznego w świetle badań ankietowych. Zeszyty naukowe uniwersytetu Szczecińskiego, vol. 833, num. 72, pp. 195-209. Retrieved from: http://www.wneiz.univ.szczecin.pl/nauka_wneiz/frfu/72-2014/FRFU-72-195.pdf

Volkova, V. N., \& Emelyanov, A. A. (2006). Teoriya sistem i sistemnyj analiz v upravlenii organizaciyami: Spravochnik [Systems theory and systems analysis in organization management: Handbook]. Moskow: Finance and statistics. 